\title{
Factors affecting the hydraulic performance of infiltration based SUDS in clay
}

Bockhorn, B.; Klint, K.E.S.; Locatelli, Luca; Park, Y.; Binning, Philip John; Sudicky, E.; Jensen, Marina Bergen

Published in:

Urban Water Journal

Link to article, DOI:

$10.1080 / 1573062 X .2015 .1076860$

Publication date:

2017

Document Version

Peer reviewed version

Link back to DTU Orbit

Citation (APA):

Bockhorn, B., Klint, K. E. S., Locatelli, L., Park, Y., Binning, P. J., Sudicky, E., \& Jensen, M. B. (2017). Factors affecting the hydraulic performance of infiltration based SUDS in clay. Urban Water Journal, 14(2), 125-133. https://doi.org/10.1080/1573062X.2015.1076860

\section{General rights}

Copyright and moral rights for the publications made accessible in the public portal are retained by the authors and/or other copyright owners and it is a condition of accessing publications that users recognise and abide by the legal requirements associated with these rights.

- Users may download and print one copy of any publication from the public portal for the purpose of private study or research.

- You may not further distribute the material or use it for any profit-making activity or commercial gain

- You may freely distribute the URL identifying the publication in the public portal 


\section{Factors affecting the hydraulic performance of infiltration based SUDS in clay}

3 Abstract

4 The influence of small scale soil heterogeneity on the hydraulic performance of infiltration based

5 SUDS was studied using field data from a clayey glacial till and groundwater simulations with the

6 integrated surface water and groundwater model HydroGeoSphere. Simulations of homogeneous

7 soil blocks with hydraulic properties ranging from sand to clay showed that infiltration capacities

8 vary greatly for the different soil types observed in glacial till. The inclusion of heterogeneities

9 dramatically increased infiltration volume by a factor of 22 for a soil with structural changes above 10 and below the $\mathrm{CaCO}_{3}$ boundary. Infiltration increased further by $8 \%$ if tectonic fractures were 11 included and by another $61 \%$ if earthworm burrows were added. Comparison of HydroGeoSphere 12 infiltration hydrographs with a simple soakaway model (Roldin et al. 2012) showed similar results 13 for homogenous soils but indicated that exclusion of small scale soil physical features may greatly 14 underestimate hydraulic performance of infiltration based SUDS.

\section{Keywords}

17 Infiltration; Stormwater modelling; SUDS 


\section{Introduction}

Sustainable urban drainage systems (SUDS), also referred to as Water Sensitive Urban Design (WSUD), are used to mimic the natural water balance, often through stormwater infiltration into the soil. Infiltration based SUDS have various forms: rain gardens or infiltration basins collect stormwater directly at the surface or very close to it; whereas soakaways, or infiltration trenches, infiltrate stormwater underground (e.g. Hoyer et al. 2011, Freni et al. 2004). The utilization of the device allows for both quantitative and qualitative control of stormwater runoff during and after rain events and their design is based on inflow, outflow and detention water volumes (Freni et al. 2009, Campisano et al. 2011, Creaco and Franchini 2012). The efficiency of an infiltration device is dependent on the hydraulic properties of the surrounding soil.

Many soils in the Northern Hemisphere are derived from deposits of the last Weichselian glaciation (Houmark-Nielsen 1999). Though they generally have a high clay content and low matrix permeability, they are highly heterogeneous with hydraulic conductivities varying by several orders of magnitude (Fredericia 1990, Klint 2001, Nilson 2001).

Infiltration capacities also vary with depth due to changes in soil structure. Macropores like fractures, root holes and earthworm burrows have a major effect on infiltration, especially in low permeable soils (Klint and Gravesen 1999). For example, anecic earthworm species increase infiltration rates since they create semi-permanent to permanent vertical burrows into deep soil layers (Edwards 2004, Lee 1985). Root holes can also serve as important pathways for water flow in soils (Jarvis 2007) and have been studied by many authors. Meek et al. (1989) observed increased ponded infiltration rates by a factor of 2-3 under a 3-year old alfalfa stand compared to loose soil. Root holes are therefore likely to lead to increased infiltration rates in SUDS located in vegetated infiltration settings. In addition vegetation improves conditions for earthworms by increasing the $\mathrm{C}$ and $\mathrm{N}$ content in the soil (Smetak et al. 2011). Earthworm burrows often have a direct connection to the surface and a greater aperture than fractures and so have a greater effect on enhanced stormwater infiltration than fractures which usually start at greater depths. Macropores become hydraulically active in wet soil when the soil matric potential exceeds the macropores entry potential, but they do not conduct water in relatively dry soil, so that they can, depending on the degree of saturation, either serve as pathways for rapid downward movement of water or function as capillary barriers in the vadose zone (Wang and Narasimhan 1985). Preferential flow patterns can be identified with the help of dye tracer experiments (Jørgensen et al. 2002). 
The $\mathrm{CaCO}_{3}$ boundary usually lies in the upper 1.3 to 2.0 meters of the tills, with $\mathrm{CaCO}_{3}$-free conditions above the boundary and $\mathrm{CaCO}_{3}$-rich conditions below. The $\mathrm{CaCO}_{3}$-free soil layers usually have a higher permeability and matrix porosities than the soil layers below, both due to the dissolution of $\mathrm{CaCO}_{3}$ and the presence of densely spaced and randomly orientated desiccation fractures (Klint and Gravesen 1999, Rosenbom et al. 2009).

Methods are available to account for soil heterogeneity in models in order to simulate the performance of stormwater infiltration based SUDS (e.g. Roldin et al. 2012) but their performance is dependent on the accuracy of the input data and often hydrogeological models lack sufficient geological information (e.g. Hansen et al. 2013). Sophisticated hydrological processes such as macropore flow have not previously been incorporated into stormwater models (Elliott and Trowsdale 2007). However, since macropores are ubiquitous features in many types of sediments, it is important to include their characteristics in models if we wish to predict the hydraulic performance of infiltration based SUDS.

While root holes have not yet been included in models, empirical studies of rain gardens have shown increased infiltration around root holes compared to bare soils. These root holes have proven to be effective to prevent clogging of rain gardens from debris input (Virahsawmy et al. 2014).

Observations of infiltration based SUDS have shown that their hydraulic performance often differs from model predictions, for example infiltration capacities of rain gardens are often underestimated which results in oversizing (Backhaus and Fryd 2013). Soakaways have been shown to have high failure rates due to poor maintenance, inappropriate siting or high debris input (Woods-Ballard et al. 2007).

Fractures and biopores are ubiquitous in soils. This study aims to show that these small scale geological features have a significant effect on infiltration capacities, and should be considered when positioning and sizing infiltration based SUDS. The paper focuses on clayey tills and the effect on infiltration rates of small scale features like $\mathrm{CaCO}_{3}$ poor and rich soil layers, earthworm burrows and tectonic fractures. Geological data characterizing a clayey till were employed with the discrete fracture model HydroGeoSphere (Therrien et al. 2009, Aquanty Inc. 2013) in simulations of variably saturated flow. Infiltration rates of four different homogenous soils were in a first step compared to infiltration rates produced with a simple soakaway model by Roldin et al. (2012) to investigate whether the soakaway model works well for homogeneous conditions. In a second step 
infiltration rates of the homogenous soils were compared to infiltration rates obtained in structured, macroporous soils. Based on the findings this paper discusses implications for maintenance and siting of infiltration based SUDS.

\section{Study area}

To illustrate the importance of soil heterogeneity for SUDS performance data was obtained from a study area situated on an undulating till plain dominated by primarily basal sandy and clayey till, located approximately $20 \mathrm{~km}$ west of Copenhagen in Denmark. The site is representative for many formerly glaciated areas of the Northern Hemisphere. In a previous study Bockhorn et al. (2014) refined a geological map of the area on scales $200 \mathrm{~m}$ x $200 \mathrm{~m}$ using spear auger mapping to scales of $5 \mathrm{~m} \times 5 \mathrm{~m} / 10 \mathrm{~m} \times 10 \mathrm{~m}$ at a $0.8-1.0 \mathrm{~m}$ depth. Sediments samples ranged from sandy tills to lacustrine postglacial clays in a depression (Figure 1). The study area is surrounded by houses, parking lots and roads and therefore represents a common urban setting.
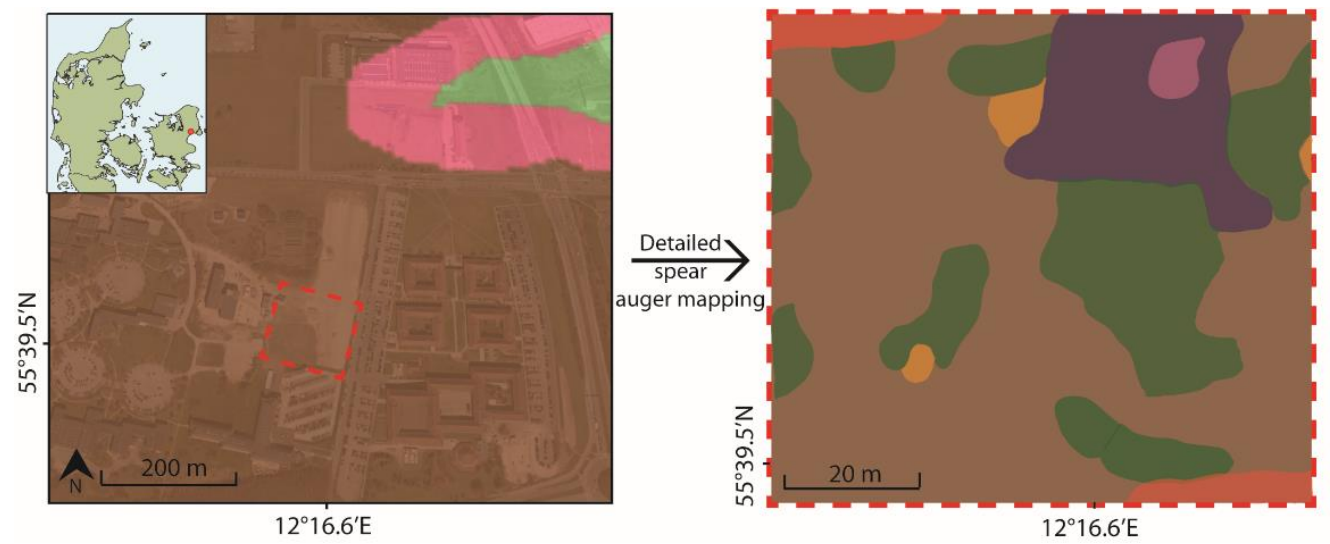

Freshwater formations

Meltwater sand and gravel

Lacustrine clay

Clayey till

Sandy clayey till Sandy till

$12^{\circ} 16.6^{\prime} \mathrm{E}$

Figure 1. Study area on a traditional geological map with $200 \mathrm{~m}$ by $200 \mathrm{~m}$ resolution (left).

Same area after refining with spear auger mapping with grid-sizes $5-10 \mathrm{~m}$ (right). Study area marked with red dotted line.

\section{Material and Methods}

\subsection{Tracer test}

To characterize the properties of local small scale soil physical features and to determine the macropore distribution, a tracer experiment was carried out in May 2012. The observed macropore distribution is incorporated into the modeling simulations for a realistic prediction of infiltration 
behavior. Brilliant Blue was used as a tracer and applied to a $2.0 \mathrm{~m} \times 0.5 \mathrm{~m}$ area. Before tracer application, the grass covered top soil was carefully removed to approximately $30 \mathrm{~cm}$ depth and a vacuum cleaner was used to clean the exposed surface to avoid smearing and clogging of the macropores by loose sediment. The trench was stabilized with a wooden frame and covered with gravel. Tap water was infiltrated over a period of several hours until saturated conditions in the soil column under the trench were achieved, and then the tracer was applied (20 1 of Brilliant Blue solution), so that the dye only migrates into hydraulic active macropores. The trench was covered with a tarpaulin to minimize disturbance by outside factors. Four days after tracer application the site was excavated to a depth of $150 \mathrm{~cm}$, corresponding to the location of the water table. The density of the dyed fractures was measured along vertical and horizontal scan-lines at $25 \mathrm{~cm}$ intervals on a vertical wall of the excavation pit. The density of dyed earthworm burrows was determined on horizontal planes at $25 \mathrm{~cm}$ depth intervals (Figure 2). The $\mathrm{CaCO}_{3}$ boundary was determined by addition of $10 \% \mathrm{HCl}$.
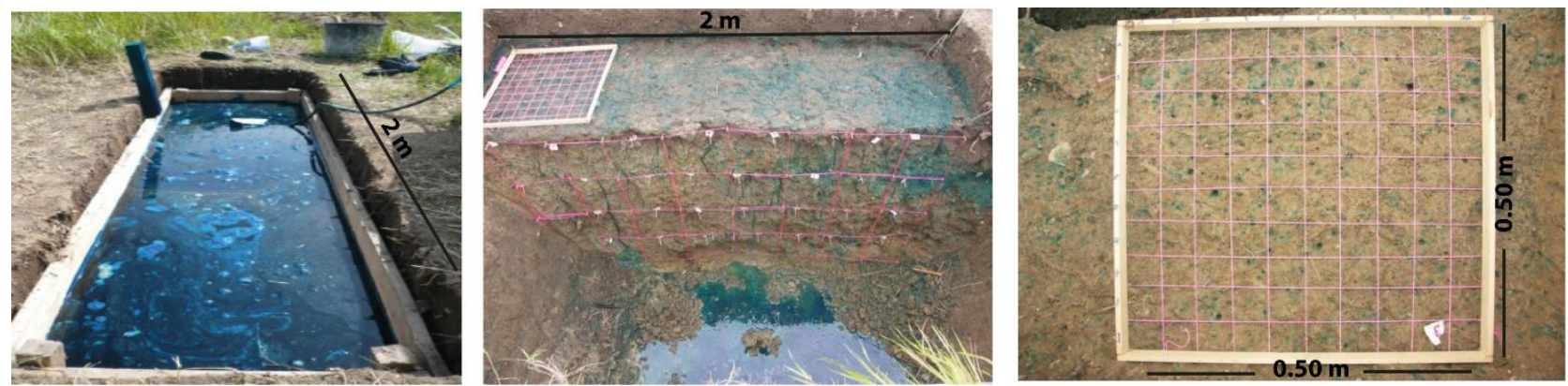

Figure 2. Left: set-up of tracer experiment to determine fracture and earthworm burrow distribution. Middle: exposure of vertical wall four days after tracer application for macropore analysis. Right: counting of earthworm burrows with the help of a $5 \mathrm{~cm} \mathrm{x} 5 \mathrm{~cm}$ grid in a wooden frame.

\subsection{Model simulations}

This study employed HydroGeoSphere which is a three-dimensional control-volume finite element model that simulates surface water flow and unsaturated flow in discretely fractured or nonfractured porous media. Unsaturated flow is simulated by a modified form of Richards' Equation:

$$
-\nabla\left(-\bar{K} \cdot k_{r} \nabla(\psi+z)\right)+\Gamma_{e x} \pm Q=\frac{\partial}{\partial t}\left(\theta_{s} S_{w}\right)
$$


where $\bar{K}$ is the hydraulic conductivity tensor, $k_{r}$ is the relative permeability, $\psi$ is the pressure head, $\mathrm{z}$ is the elevation head, [ex is the subsurface fluid exchange rate with the surface domain, $Q$ is a subsurface fluid source or sink, $\theta s$ is the saturated water content, and $S_{w}$ is the water saturation.

Fracture flow is simulated in two dimensions and a common node approach is used to couple flow in the fractures and matrix, based on the assumption of continuity of hydraulic head between the two domains. Flow velocities in the fractures are determined by the cubic law (Witherspoon et al. 1980). Retention and relative permeability for both fractures and porous media are given by van Genuchten functions or in a table form. For seamless integration of surface and subsurface flow, the porous medium is coupled with an overland domain and surface flow is described by the diffusionwave approximation of the Saint Venant equations:

$$
\frac{\partial \emptyset 0}{\partial \mathrm{t}}+\frac{\partial(\overline{\mathrm{v}} \mathrm{x} 0 \mathrm{~d} 0)}{\partial \mathrm{x}}+\frac{\partial(\overline{\mathrm{v}} \mathrm{y} 0 \mathrm{~d} 0)}{\mathrm{dy}}+\mathrm{d} 0\lceil 0 \pm \mathrm{Q} 0=0
$$

where $\emptyset 0$ is the surface porosity, $\bar{v}_{\text {xo }}$ and $\bar{v}_{\text {yo }}$ are the vertically averaged flow velocity in the $\mathrm{x}$ and $\mathrm{y}$ directions, respectively, $d_{\mathrm{o}}$ is the water depths, $\Gamma_{o}$ is the fluid exchange rate with the subsurface, and $Q_{o}$ is a surface fluid source or sink (Therrien et al. 2009).

The infiltration rates and emptying times simulated by HydroGeoSphere were compared to those obtained by the simple soakaway model presented by Roldin et al. (2012). The model of Roldin et al. (2012) is based on the soakaway mass balance:

$$
\mathrm{n} \cdot \mathrm{l} \cdot \mathrm{w} \cdot \frac{\mathrm{dh}}{\mathrm{dt}}=\mathrm{Q}_{\text {in }}-\mathrm{Q}_{\text {out }}
$$

where $n$ is the porosity of the soakaway filling material, $l$ is the length of the soakaway, $w$ is the width of the soakaway, $h$ is the water level in the soakaway, $t$ is the time and $Q_{\text {in }}$ and $Q_{\text {out }}$ are the inflow and outflow rates from the soakaway. $Q_{\text {out }}$ is the sum of the overflow rate and the infiltration rate. The infiltration rate $f$ is assumed to be equal to the product between the hydraulic conductivity and the wetted area of the soakaway:

$$
f=k l w+k 2 h(l+w)
$$

where $k$ is the soil hydraulic conductivity and $k l w$ represents the infiltration from the bottom of the soakaway whereas $k 2 h(l+w)$ the infiltration from the sides. The storage volume is described as $V=l w d / n$, where $d$ is the height of the soakaway and $n$ is the porosity of the filling material. 
The same soil physical parameters were employed as were used in the HydroGeoSphere simulations, and the infiltration rates and difference in soakaway emptying time compared for the 2 models.

\subsection{Model domains}

To assess the variability of the infiltration capacity at the site, four $150 \mathrm{~cm}$ thick homogenous domains were set up to reflect the most dominant soil types sampled at the site Soil physical parameters were used to determine retention function parameters using the data provided by Carsel and Parrish (1988) (see Table 1). The same parameters were used in the soakaway models of Roldin et al. (2013).

The weighted mean for $K_{\text {sat }}$ was determined by weighting each individual soil type by the size of the area covered.

Based on the information gained from the geological description of the excavation and the tracer test, the model was refined by adding additional soil physical features to the model domain, in the following sequence $\mathrm{CaCO}_{3}$, fractures, earthworm burrows. The macropore distribution from the 1 $\mathrm{m}^{2}$ large excavation pit was downsized to the $40.4 \mathrm{~cm}^{2}$ large model area. The homogenous clayey till is the dominant sediment type on the study area and so was used for the base scenario.

In the heterogeneous simulations, the model was subdivided into two distinct layers (above and below $\mathrm{CaCO}_{3}$ boundary). Randomly oriented desiccation fractures occur in the zone above the $\mathrm{CaCO}_{3}$ boundary and were included in the model by embedding them into the matrix using the method proposed by Rosenbom et al. (2009). Tectonic fractures and earthworm burrows were added to the domain, with the distribution of macropores being taken from the results of the field investigation. All other parameters were obtained from the study of Rosenbom et al. (2009) (Table $1)$. 
Table 1. Model input parameters used in HydroGeoSphere simulations. Parameters for sandy till, 179 clayey till, sandy clayey till and lacustrine clay were obtained from Carsel and Parrish (1988) 180 ('loamy sand', 'clay', 'sandy clay loam' and 'silty clay'). Parameters for soil layer 'above $\mathrm{CaCO}_{3}$ 181 boundary' and 'below $\mathrm{CaCO}_{3}$-boundary', and macropore parameters were obtained from Rosenbom 182 et al. (2009).

\begin{tabular}{|c|c|c|c|c|c|}
\hline Medium & Parameter & Value & Medium & Parameter & Value \\
\hline $\begin{array}{l}\text { Sandy till } \\
\text { ('loamy } \\
\text { sand') }\end{array}$ & $\begin{array}{l}\mathrm{K}_{\mathrm{sat}}[\mathrm{cm} / \mathrm{min}] \\
\text { Porosity }\left[\mathrm{cm}^{3} \mathrm{~cm}^{-3}\right] \\
\text { Residual saturation }\left[\mathrm{cm}^{3} \mathrm{~cm}^{-3}\right] \\
\text { Van Genuchten Paramter: } \\
\text { Alpha }[1 / \mathrm{cm}] \\
\text { Beta }\end{array}$ & $\begin{array}{l}0.243054 \\
0.41 \\
0.057 \\
0.124 \\
2.28\end{array}$ & $\begin{array}{l}\text { Clayey till } \\
\text { ('clay') }\end{array}$ & $\begin{array}{l}\mathrm{K}_{\mathrm{sat}}[\mathrm{cm} / \mathrm{min}] \\
\text { Porosity }\left[\mathrm{cm}^{3} \mathrm{~cm}^{-3}\right] \\
\text { Residual saturation }\left[\mathrm{cm}^{3} \mathrm{~cm}^{-3}\right] \\
\text { Van Genuchten Paramter: } \\
\text { Alpha } \\
\text { Beta }\end{array}$ & $\begin{array}{l}0.0033 \\
0.38 \\
0.068 \\
0.0088 \\
1.09\end{array}$ \\
\hline $\begin{array}{l}\text { Sandy } \\
\text { clayey till } \\
\text { ('sandy } \\
\text { clay loam') }\end{array}$ & $\begin{array}{l}\mathrm{K}_{\mathrm{sat}}[\mathrm{cm} / \mathrm{min}] \\
\text { Porosity }\left[\mathrm{cm}^{3} \mathrm{~cm}^{-3}\right] \\
\text { Residual saturation }\left[\mathrm{cm}^{3} \mathrm{~cm}^{-3}\right] \\
\text { Van Genuchten Paramter: } \\
\text { Alpha } \\
\text { Beta }\end{array}$ & $\begin{array}{l}0.02183 \\
0.39 \\
0.1 \\
0.059 \\
1.48\end{array}$ & $\begin{array}{l}\text { Lacustrine } \\
\text { clay } \\
\text { ('silty clay') }\end{array}$ & $\begin{array}{l}\mathrm{K}_{\mathrm{sat}}[\mathrm{cm} / \mathrm{min}] \\
\text { Porosity }\left[\mathrm{cm}^{3} \mathrm{~cm}^{-3}\right] \\
\text { Residual saturation }\left[\mathrm{cm}^{3} \mathrm{~cm}^{-3}\right] \\
\text { Van Genuchten Paramter: } \\
\text { Alpha } \\
\text { Beta }\end{array}$ & $\begin{array}{l}0.000333 \\
0.36 \\
0.070 \\
0.005 \\
1.09\end{array}$ \\
\hline $\begin{array}{l}\text { Above } \\
\mathrm{CaCO}_{3} \\
\text { boundary }\end{array}$ & $\begin{array}{l}\mathrm{K}_{\mathrm{sat}}[\mathrm{cm} / \mathrm{min}] \\
\text { Porosity }\left[\mathrm{cm}^{3} \mathrm{~cm}^{-3}\right] \\
\text { Residual saturation }\left[\mathrm{cm}^{3} \mathrm{~cm}^{-3}\right] \\
\text { Van Genuchten Paramter: } \\
\text { Alpha } \\
\text { Beta }\end{array}$ & $\begin{array}{l}0.324 \\
0.36 \\
0.08 \\
0.00698 \\
2.0\end{array}$ & $\begin{array}{l}\text { Tectonic } \\
\text { fractures }\end{array}$ & $\begin{array}{l}\text { Aperture }[\mathrm{cm}] \\
\text { Residual saturation }\left[\mathrm{cm}^{3} \mathrm{~cm}^{-3}\right] \\
\text { Van Genuchten Paramter: } \\
\text { Alpha } \\
\text { Beta }\end{array}$ & $\begin{array}{l}0.01 \\
0.01 \\
0.04687 \\
2.29719\end{array}$ \\
\hline $\begin{array}{l}\text { Below } \\
\mathrm{CaCO}_{3} \\
\text { boundary }\end{array}$ & $\begin{array}{l}\mathrm{K}_{\text {sat }}[\mathrm{cm} / \mathrm{min}] \\
\text { Porosity }\left[\mathrm{cm}^{3} \mathrm{~cm}^{-3}\right] \\
\text { Residual saturation }\left[\mathrm{cm}^{3} \mathrm{~cm}^{-3}\right] \\
\text { Van Genuchten Paramter: } \\
\text { Alpha } \\
\text { Beta }\end{array}$ & $\begin{array}{l}0.000108 \\
0.31 \\
0.007 \\
0.00293 \\
1.07442\end{array}$ & $\begin{array}{l}\text { Earthworm } \\
\text { burrows }\end{array}$ & $\begin{array}{l}\text { Aperture }[\mathrm{cm}] \\
\text { Residual saturation }\left[\mathrm{cm}^{3} \mathrm{~cm}^{-3}\right] \\
\text { Van Genuchten Paramter: } \\
\text { Alpha } \\
\text { Beta }\end{array}$ & $\begin{array}{l}0.4 \\
0.01 \\
0.1 \\
2.0\end{array}$ \\
\hline
\end{tabular}




\subsection{Mesh and Boundary conditions}

The same boundary conditions were used for all simulations. The nodal spacing in the $\mathrm{z}-$ and $\mathrm{x}-$ directions was $5.0 \mathrm{~cm}$, but at the termination of the macropores the grid was refined to 0.1 with a multiplication factor of 1.5 above, below and adjacent to the macropores. The y-axis node spacing was $0.4 \mathrm{~cm}$ which equals the average diameter of the earthworm burrows.

Tectonic fractures and earthworm burrows were represented as 2D-planes in the model with a dip of 90 degrees and a uniform aperture along the macropore. Water retention characteristics are taken from (Rosenbom et al. 2009).

$K_{s a t}$ for the 2D-planes was given by $K_{f s=} \frac{\rho g}{12 \mu}(2 b)^{2}$ where $\rho$ is the fluid density, $g$ is gravitational acceleration, $\mu$ is the dynamic viscosity, $2 b$ is the fracture aperture and $K_{f s}$ is the saturated hydraulic conductivity of a single fracture $\left[\mathrm{LT}^{-1}\right]$, resulting in $K_{f s(\text { fracture })}=0.817 \mathrm{~cm} / \mathrm{min}$ and $K_{f s(\text { biopore })}=1307$ $\mathrm{cm} / \mathrm{min}$.

The water table at $1.5 \mathrm{~m}$ depth served as the lower boundary as observed in the summer of 2011 when the fieldwork took place and was kept constant for the duration of the simulation. There is no flow through the sides of the model.

An infiltration flux of $0.25 \mathrm{~cm} / \mathrm{min}$ was applied to the surface domain for 100 minutes and increased to $0.70 \mathrm{~cm} / \mathrm{min}$ for the simulations of the heterogeneous and macroporous soil columns. The flux represents the stormwater runoff from a large nearby impervious area diverted to the smaller infiltration unit. A storage height was set to $30 \mathrm{~cm}$ for the infiltration flux of $0.25 \mathrm{~cm} / \mathrm{min}$ and to $70 \mathrm{~cm}$ for the infiltration flux of $0.70 \mathrm{~cm} / \mathrm{min}$ to prevent lateral surface flow.

The total simulation period varied from 50 hours to 80 days. The initial time step was $10^{-8}$ min with a maximum time step multiplier of 2 . 


\subsection{Tracer test}

208 The results of the field investigations are presented in Figure 3. They include the distribution of 209 hydraulically active earthworm burrows and tectonic fractures across the soil profile and the 210 location of the $\mathrm{CaCO}_{3}$ at approximately $130 \mathrm{~cm}$ depth, with randomly oriented desiccation fractures 211 in the $\mathrm{CaCO}_{3}$ free soil layer

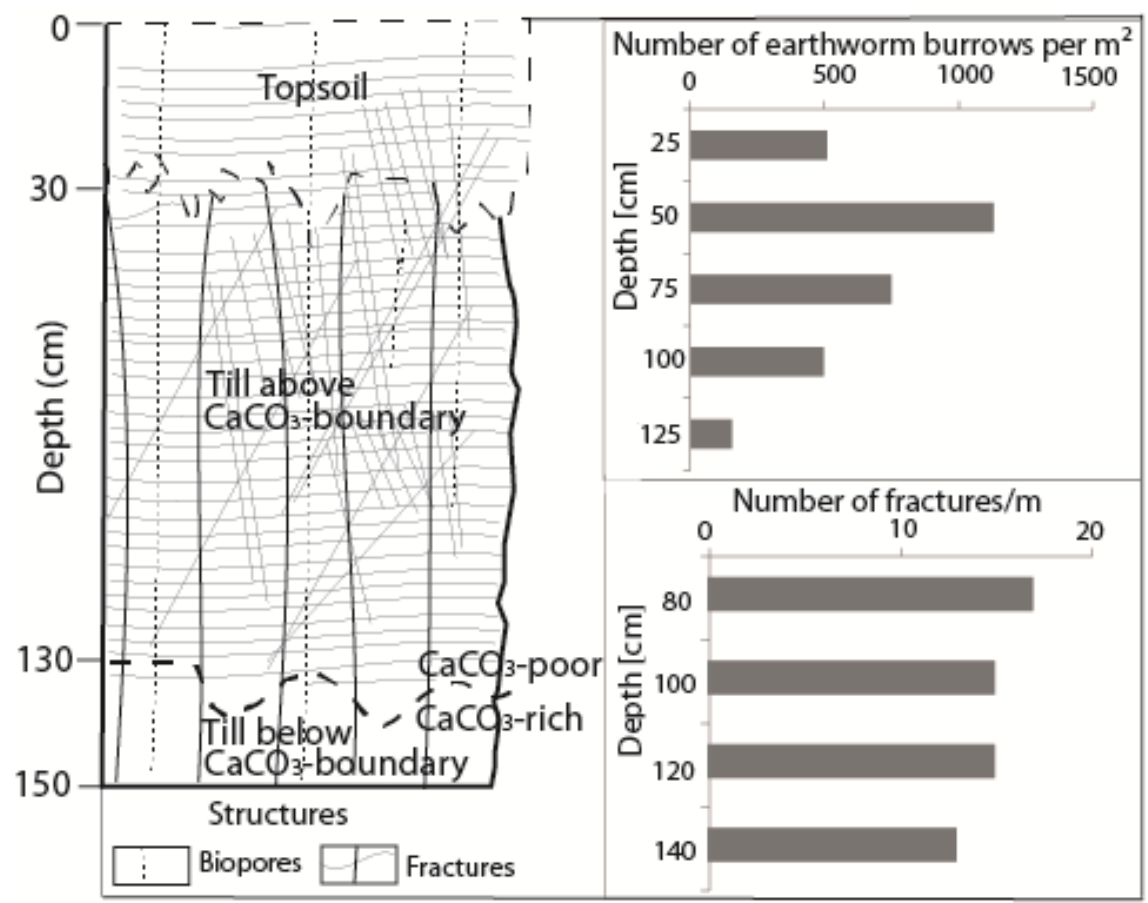

Figure 3. Geological log as determined in the excavation including distribution of macropore 214 (vertical tectonic fractures and earthworm burrows).

\subsection{Model results}

The simplified model scenarios are shown in Figure 4. 


\section{a)}

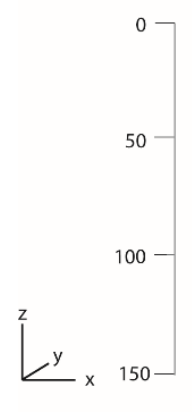

a)
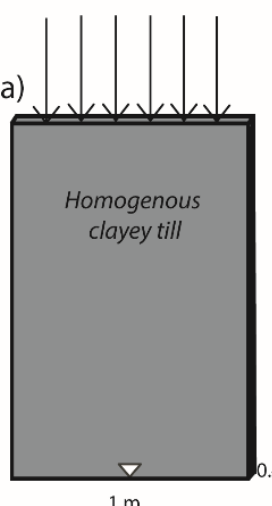

b)
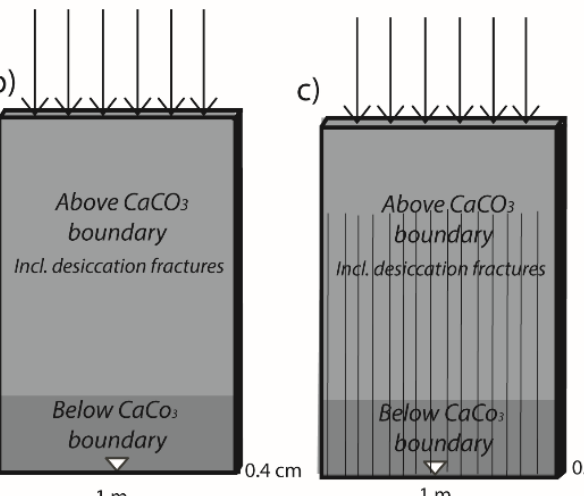

d)

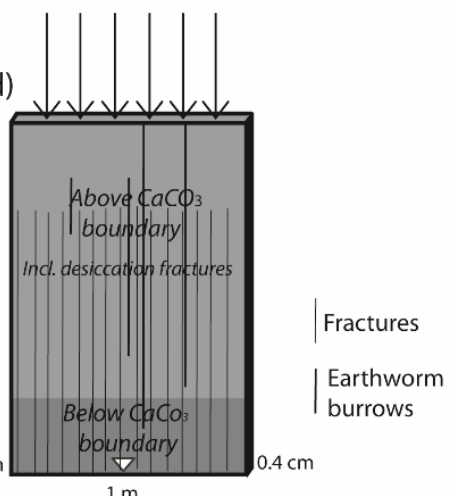

Figure 4. Different model domains according to geological description and macropore observations.

221 The weighted mean of $K_{\text {sat }}$ for the study area was $0.0648 \mathrm{~cm} / \mathrm{min}$, compared to $0.0033 \mathrm{~cm} / \mathrm{min}$ for 222 the dominant soil type covering the large scale geological map. In this case, an incorporation of 223 detailed knowledge on the sedimentary distribution increases the estimated $K_{\text {sat }}$ by a factor of 224 almost 20.

225 The infiltration rates from the HydroGeosSphere and Roldin et al. (2012) models are shown in 226 Figure 5. These rates are of the same order of magnitude, demonstrating that the simple soakaway 227 model gives infiltration rates in homogenous soils similarly to the HydroGeosSphere model. 228 However, there is a significant difference in the initial shape of the hydrograph.

229 Results show the differences within the water balance for the different soil types with clear 230 differences in infiltration behavior over time. Except for the sandy soil, stormwater input exceeds 231 the infiltration capacity and water accumulates on the surface. By examining the area under the 232 curves, the sandy soil can be seen to handle $94 \%$ more water than the lacustrine clay. 


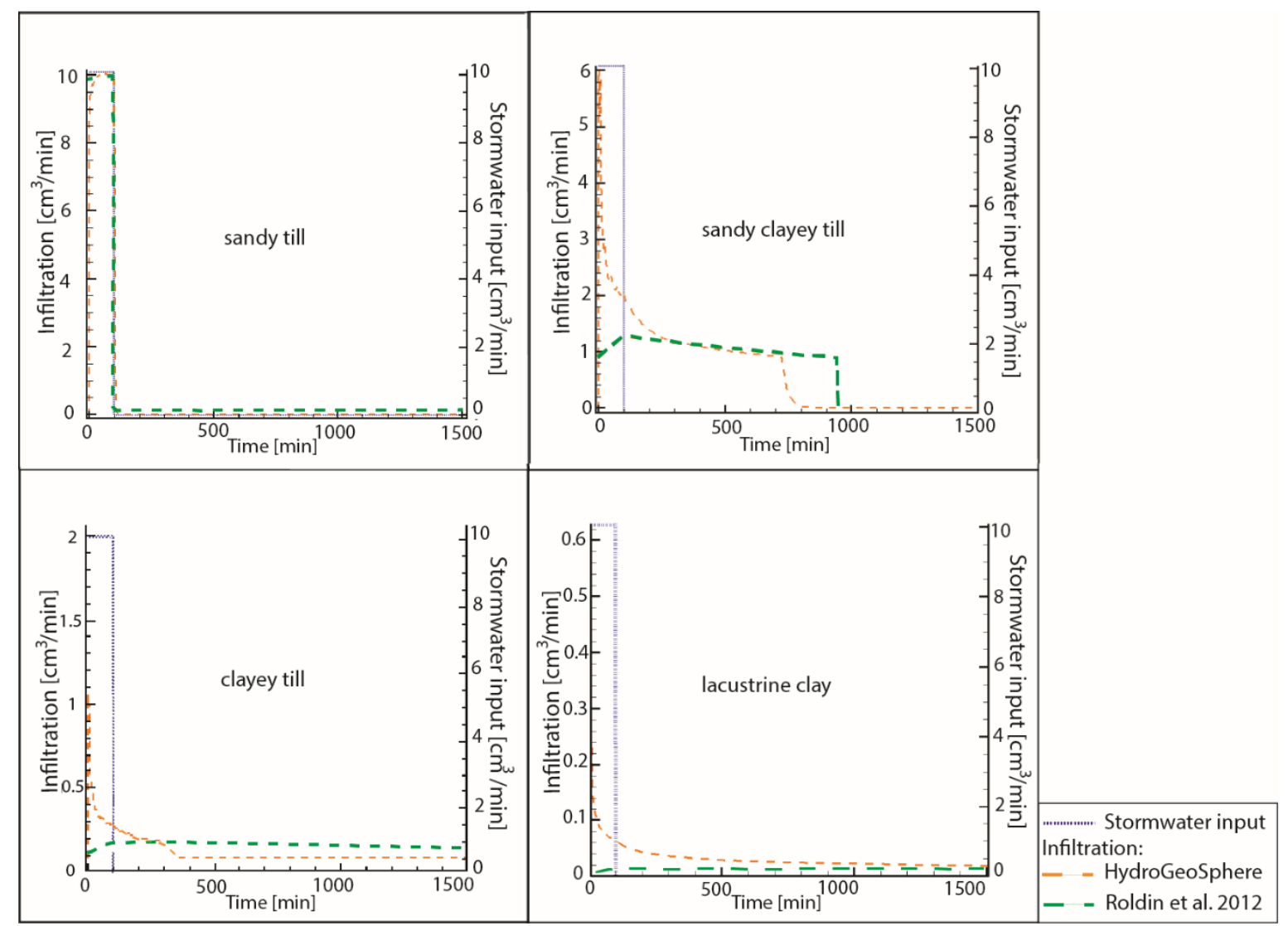

234 Figure 5. Infiltration rates into the four different soil types observed in the study area as simulated with HydroGeoSphere and the model from Roldin et al. (2012).

236 The soakaway emptying time obtained from the two models is shown in Table 2. The model from 237 Roldin et al. (2012) approximates the results obtained from HydroGeoSphere within a range of 238 approximately $\pm 50 \%$. This uncertainty is small compared to the uncertainty resulting from different 239 soil types.

240 Table 2: Emptying times obtained from HydroGeoSphere and the model from Roldin et al. (2012).

\begin{tabular}{|l|l|l|l|l|}
\hline & Roldin-model & $\begin{array}{l}\text { Roldin-model assuming } \\
\text { infiltration only from the } \\
\text { soakaway bottom }\end{array}$ & HydroGeoSphere & $\begin{array}{l}\text { Roldin- } \\
\text { model/HydroGeoSphere }\end{array}$ \\
\hline Sandy till & 2 minutes & 3 minutes & 26 minutes & $*$ \\
\hline Sandy clayey till & 14.1 hours & 17.4 hours & 12.5 hours & Overestimates 13-39\% \\
\hline Clayey till & 4.2 days & 5.1 days & 8.6 days & Underestimates 51-41\% \\
\hline Lacustrine clay & 42 days & 52 days & 75 days & Underestimates $44-31 \%$ \\
\hline
\end{tabular}

\footnotetext{
* It is not considered relevant to compare emptying time in the scale of minutes
} 
242 Figure 6 displays the infiltration behavior for the heterogeneous clayey till scenarios presented in 243 Figure 4 for two different stormwater inputs $(0.25 \mathrm{~cm} / \mathrm{min}$ over $100 \mathrm{~min}$ and $0.70 \mathrm{~cm} / \mathrm{min}$ over 100 $244 \min )$.

245 As expected, infiltration capacity is increasing when soil structural features such as macropores are 246 included. In the first scenario the capacity of biopore infiltration is not surpassed. The effect of 247 preferential pathways on soakaway emptying times is presented in Table 3. For the second scenario 248 emptying times vary between 17 days in a homogenous soil and 100 minutes in a soil with $\mathrm{CaCO}_{3-}$ 249 boundary, fractures and biopores.

250 Table 3. Emptying times obtained from HydroGeoSphere for four different clayey till domains and 251 two flux-boundary conditions.

259 At a water inflow rate of $70 \mathrm{~cm} / \mathrm{min}$ a 22 -fold increase in infiltration volume was observed in the 260 clayey till column when the $\mathrm{CaCO}_{3}$ boundary and desiccation fractures were included as compared 261 to the homogenous clayey soil. Infiltration shows a further increase in volume by $8 \%$ in a fractured 262 soil and an increase by another $61 \%$ in a fractured soil perforated with earthworm burrows during 263

\begin{tabular}{|l|l|l|l|l|}
\hline & $\begin{array}{c}\text { Homogenous } \\
\text { clayey till }\end{array}$ & $\begin{array}{c}\text { Clayey till with } \\
\mathrm{CaCO}_{3} \\
\text { boundary }\end{array}$ & $\begin{array}{c}\text { Fractured } \\
\text { clayey till with } \\
\mathrm{CaCO}_{3} \\
\text { boundary }\end{array}$ & $\begin{array}{c}\text { Fractured and } \\
\text { bioporous clayey till } \\
\text { with } \mathrm{CaCO}_{3} \\
\text { boundary }\end{array}$ \\
\hline $\begin{array}{l}\text { Hydrogeosphere } \\
\text { (flux }=0.25 \mathrm{~cm} / \mathrm{min} \\
\text { over } 100 \mathrm{~min})\end{array}$ & 8.6 days & 29 minutes & 21 minutes & 0 \\
\hline $\begin{array}{l}\text { Hydrogeosphere } \\
\text { flux }=0.70 \mathrm{~cm} / \mathrm{min} \\
\text { over } 100 \mathrm{~min})\end{array}$ & 17 days & 235 minutes & 210 minutes & 100 minutes \\
\hline
\end{tabular}
the duration of stormwater input. 

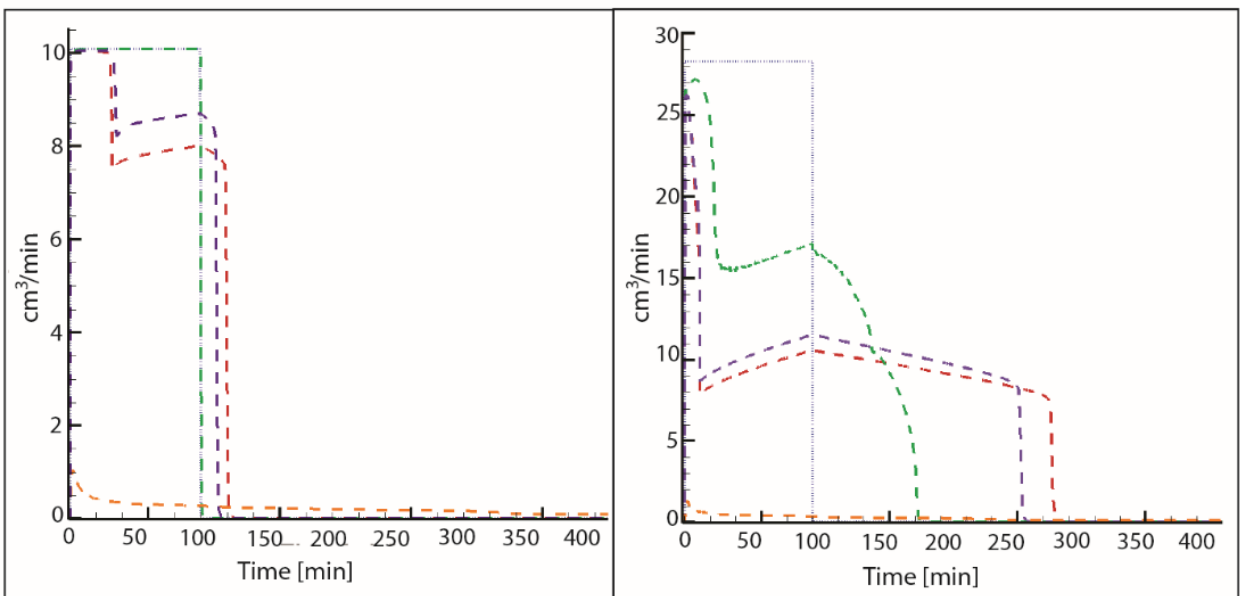

.............. Stormwater input Infiltration:

- - - - Fractured clayey till with biopores - - - - Fractured clayey till - - - Clayey till with CaCO3-boundary

265 Figure 6. Infiltration rates for different clayey till domains and two inflow-boundary conditions. 266 Left: Water application rate is $0.25 \mathrm{~cm} / \mathrm{min}$. Right: Water application rate is $0.70 \mathrm{~cm} / \mathrm{min}$ (right).

The importance of earthworm burrows for enhanced infiltration was also shown in the saturation profiles shortly before and after the rain event (Figure 7). Drainage (decrease in saturation) was faster along the biopores compared to drainage along the tectonic fractures and in the matrix.
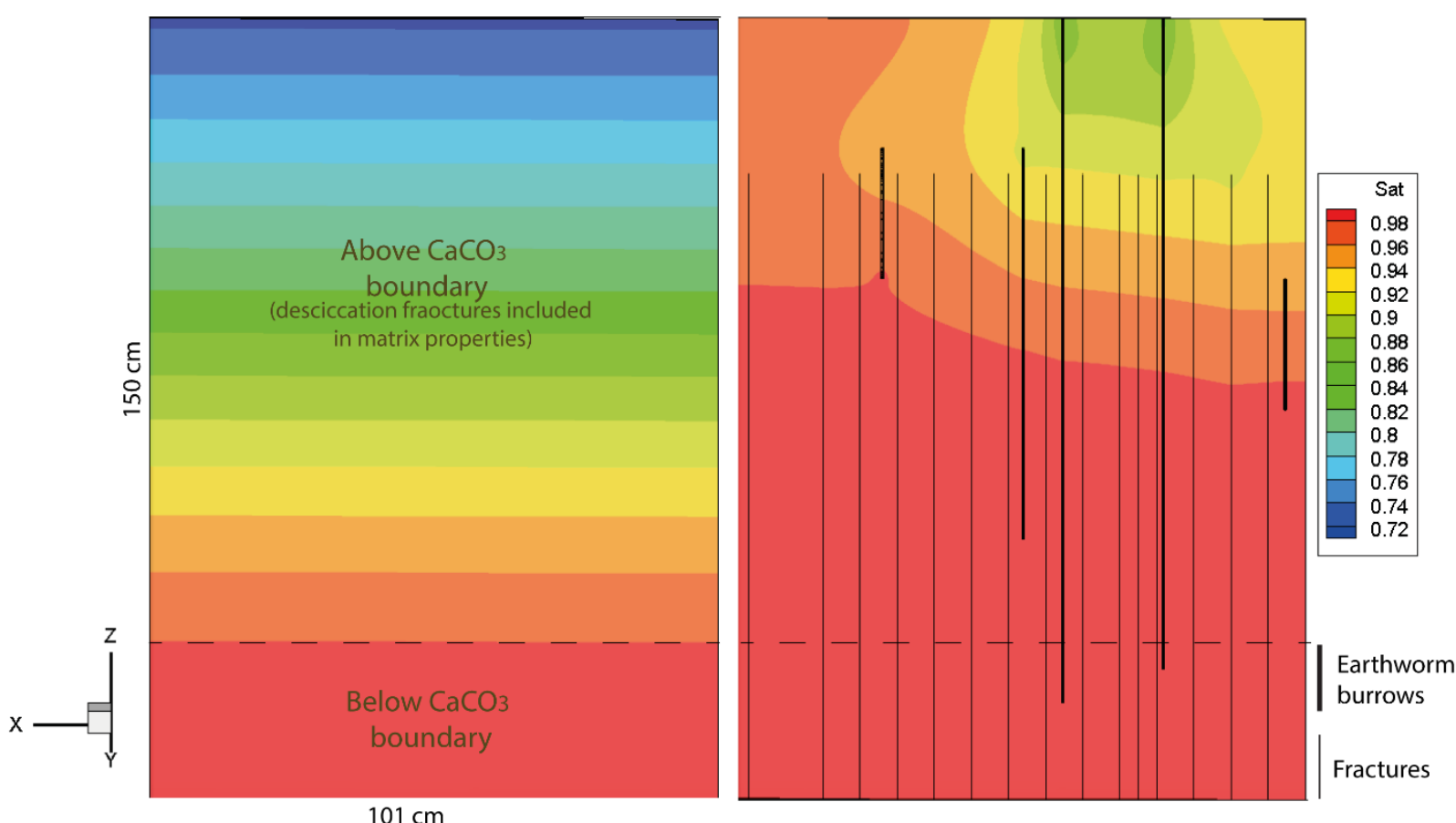
272 Figure 7. Saturation profile of clayey till column perforated with macropores before water

273 application (left) and at termination of water application (right). Clayey till column model domain 274 equals outer right column in Figure 5.

\section{Discussion}

\subsection{Differences in model results}

Significant differences in the initial shape of the infiltration hydrograph obtained by the Roldin model and HydroGeoSphere model are observed. This is because the model from Roldin et al. (2012) only considers the water level in the soakaway and not the matrix suction in the initially dry soil.

\subsection{Model limitations}

In these simulations no-flow boundary conditions were chosen on the model sides which may have led to an underestimation of the infiltration rates due to the presence of an artificial flow-barrier. In reality water would also move horizontally through the model boundary.

All macropores were represented as vertical 2D planes which might have led to overestimation of infiltration rates due to dominant vertical downward-flow. On the other hand, sub-horizontal freezethaw fractures and horizontal earthworm burrows can be interconnected resulting in a network of water pathways which may have led to underestimation of infiltration rates in the model. Studies by Tsakiroglou et al. (2012) document that flow in single fractures is not well represented by single vertical 2D planes but more likely by a 2D channel network.

Since this study was based on field observations at small scale with a well-defined geometry of the porous medium and fractures, a discrete fracture approach can best describe the flow conditions (Samardzioska and Popov 2005, Rosenbom et al. 2009). However, at larger scales it is difficult to account for every single fracture because of the computational cost of the simulations. For these cases it can be advantageous to employ a dual porosity approach (Samardzioska and Popov 2005). A dual porosity approach divides the domain into two separate pore systems, the porous matrix and the fractures, with separate hydraulic and transport properties. They interact by exchanging water and solutes in response to pressure head and concentration gradients (Gerke and van Genuchten 1993). 
301

302

303

The simulations did not account for a potential biopore coating. Several studies indicate that walls of earthworm burrows can be lined with a thin hydrophobic mucus layer, secreted by earthworms. When water flows into a biopore, coating along the burrow walls can prevent its movement back into the matrix (Gerke and Kohne 2002, Rosenbom et al. 2009). However, no studies have been carried out yet successfully documenting the influence of biopore-coating on infiltration rates.

\subsection{Risk of contaminant transport through preferential pathways}

The simulations focused on the enhanced infiltration of stomwater runoff when macropores are present. However, it should be noted that increased infiltration rates enhance the risk of groundwater degradation by contaminant transport through the same preferential flow routes. Stormwater runoff often carries contaminants such as heavy metals, organic micro-pollutants, nutrients and suspended solids (Butler and Davis 2000). Experimental as well as modelling studies have shown that contaminants can be transported rapidly along fractures (e.g. Hinsby et al. 1996, Jørgensen et al. 1998, Sidle et al. 1998), sometimes even when matrix suction is high (Rosenbom et al. 2009). Infiltration of stormwater runoff should only be considered if either a special treatment facility upstream is installed (e.g. Göbel et al. 2008) or if non- or less polluted roof runoff is infiltrated. Moreover, infiltration devices should only be employed in areas far from aquifers of interest for drinking water supply.

\subsection{Improved stormwater management practices in cities and maintenance implications}

In this study the presence of earthworm burrows decreases the drainage time of the soakaway by 110 minutes. Rain gardens or infiltration basins may therefore have greater infiltration rates than subsurface soakaways and should be preferred if space allows. Moreover these systems can filter polluted stormwater runoff through biologically active soils and plants and so remove contaminants from the water (Davis 2007). Rain gardens and infiltration basins should be placed in locations where optimal living conditions for anecic earthworm species (e.g. Lumbricus terrestris) can be created, as the worms create deep, mainly vertical burrows for enhanced water flow into deeper soil horizons (Edwards 2004, Lee 1985), thereby improving the soil structure for increased infiltration. Smetak et al. (2011) showed that earthworm population density and diversity increases with age of the urban landscape and with the density of vegetation. Maintaining the soil structure by avoiding 
tilling of the soil in and around the infiltration based SUD may therefore lead to improved hydraulic performance of the infiltration system over time. The performance of a newly soakaway can be improved by planting and the addition of earthworms to accelerate the process of soil structure development. The resultat bioturbation will increase the hydraulic performance of the raingarden over time and clogging of the system will be reduced.

In densely built urban areas, space is often insufficient for the installation of rain gardens which are large enough to handle water from all impervious areas. In such areas a combined design of a small rain garden functioning as a sand trap and water treatment device connected to a subsurface soakaway may be an option. In that way sediment loads into the soakaway will be reduced, preventing clogging of the device and thus prolonging its life expectancy.

\section{Conclusions}

Results of this study have shown that the siting and maintenance of infiltration based SUDS are important in clayey sediments. In this study soakway emptying times simulated on homogenous soil blocks varied between a few minutes and 75 days. The hydraulic performance of soakaways can be optimized by optimal siting through a detailed geological investigation (Bockhorn et al. 2014).

Simple soakaway models such as that of Roldin et al. (2012) were shown to be applicable to simulate infiltration rates and emptying times of soakaways in homogenous sediments. However, the simple soakaway model significantly underestimates infiltration rates in heterogenous (real) soils since they do not account account for preferential flow routes like fractures and macropores.

A detailed geological site investigation is needed for accurate prediction of soakaway performance in glacial deposits because of their large geologic heterogeneity. Areas consisting mainly of low permeable clayey sediments might have patches of sandy deposits which are optimal sites for the placement of infiltration based SUDS. Models employing standard soil physical parameters should be used with care as they do not always realistically describe site specific hydrologic properties.

In low permeable clayey soils, infiltration capacities are especially sensitive to the presence of small scale soil physical features such as horizontal and vertical fractures, earthworm burrows and structural changes across the soil profile. Upper soil layers typically have increased infiltration capacities, due to the presence of horizontal desiccation fractures above the $\mathrm{CaCO}_{3}$ boundary and 
the occurrence of earthworm burrows. Earthworm burrows are most beneficial for infiltration due to their greater aperture compared to fractures and because they often have a direct connection to the surface. Rain gardens may therefore operate with greater infiltration rates than subsurface soakaways and should be preferred if space allows, especially if they are designed so that they provide optimal living conditions for earthworms.

\section{Funding}

The work was funded by the Council for Technology and Innovation in Denmark [10-093317]

\section{Acknowledgements}

The authors wish to thank MSc Daniela Lattner for her help during fieldwork campaigns.

\section{References}

Aquanty Inc. 2013: Hydrogeosphere Analytics. Available from: http://www.aquanty.com/.

Backhaus, A. and Fryd, O., 2013. The Aesthetic Performance of Urban Landscape-Based Stormwater Management Systems: A Review of Twenty Projects in Northern Europe. Journal of Landscape Architecture, 8 (2), 52-63.

Bockhorn, B., Klint, K.E.S, Jensen, M.B., 2014: Stormwater management: Methods for measuring near-surface infiltration capacity in clayey till. Geological Survey of Denmark and Greenland Bulletin, 31, 47-50.

Butler, D. and Davies, J.W., 2000. Urban drainage. E \& FN Spon, London.

Campisano A., Creaco E., Modica C. 2011. A simplified approach for the design of infiltration trenches. Water Science and Technology, 64 (6), 1362-1367.

Carsel, R. F. and Parrish, R. S., 1988. Developing joint probability distributions of soil water retention characteristics. Water Resources Research, 24(5), 755-769.

Creaco E., Franchini M. 2012. A dimensionless procedure for the design of infiltration trenches. Journal American Water Works Association (ISI), 104(9), 45-46. 
Davis, A.P., 2007. Field performance of bioretention: water quality. Environmental Engineering Science 24, 1048-1064.

Edwards, C. A., 2004. Earthworm Ecology (2nd ed.). Boca Raton, FL, USA: CRC Press.

Elliott, A. H. and Trowsdale, S. A., 2007. A review of models for low impact urban stormwater drainage. Environmental Modelling \& Software, 22 (3), 394-405.

Fredericia J., 1990. Saturated hydraulic conductivity of clay tills and the role of fractures. Nord Hydrol, 21, 119-132.

Freni, G.; Oliveri, E.; \& Viviani, G., 2004. Infiltration facilities design: comparison between simplified approaches and detailed physically based modelling. In: Proceedings of NOVATECH 2004.

Freni, G., Mannina, G., \& Viviani, G., 2009. Stormwater infiltration trenches: a conceptual modelling approach. Water Science and Technology, 60 (1), 185-99.

Gerke H.H. and van Genuchten M.T. 1993. A Dual-Porosity Model for Simulating the Preferential Movement of Water and Solutes in Structured Porous Media. Water Resources Research, 29 (2), 305-319.

Gerke, H. H. and Kohne, J. M., 2002. Estimating hydraulic properties of soil aggregate skins from sorptivity and water retention. Soil Science Society of America Journal, 66 (1), 26-36.

Göbel, P., Zimmermann, J., Klinger, C., Stubbe, H., Coldewey, W.G. 2008: Recommended urban storm water infiltration devices for different types of run-off under varying hydrogeological conditions. J. Soils Sediments, 8, 231-238.

Hansen, A.L., Refsgaard, J.C., Christensen, B.S.B. and Jensen, K.H., 2013. Importance of Including Small-Scale Tile Drain Discharge in the Calibration of a Coupled Groundwater-Surface Water Catchment Model. Water Resources Research 49 (1): 585-603.

Hinsby K., McKay L.D., Jørgensen P.R., Lenczewski M., Gerba C.P. 1996. Fracture aperture measurements and migration of solutes, and immiscible creosote in a column of clay-rich till. Ground Water 34 (6), 1065-1075.

Houmark-Nielsen, M., 1999. A lithostratigraphy of Weichselian glacial and interstadial deposits in Denmark. Bull. Geol. Soc. Denmark, 46 (1), 39-52. 
Hoyer, J., Dickhaut, W., Kronawitter, L. and Weber, B., 2011. Water Sensitive Urban Design and Inspiration for Sustainable Stormater Management in the City of the Future, Berlin: Jovis Verlag.

Jarvis, N. J., 2007. A review of non-equilibrium water flow and solute transport in soil macropores: principles, controlling factors and consequences for water quality. European Journal of Soil Science, 58 (3), 523-546.

Jørgensen, P.R., McKay, L.D., Spliid, N.H., 1998. Evaluation of chloride and pesticide transport in a fractured clayey till using large undisturbed columns and numerical modelling.Water Resources Research 34 (4), 539-553.

Jørgensen, P.R., M. Hoffmann, J.P. Kistrup, C. Bryde, R. Bossi, and K.G. Villholth. 2002. Preferential flow and pesticide transport in a clay-rich till: Field, laboratory, and modeling analysis. Water Resour. Res. 38, 1246.

Klint. K.E.S., 2001. Fractures in Glacigene Diamict deposits; Origin and Distribution. Thesis (PhD). Geological Survey of Denmark and Greenland.

Klint. K.E.S. and Gravesen P., 1999. Fractures and Biopores in Weichselian Clayey Till Aquitards at Flakkebjerg, Denmark. Nordic Hydrology, 30, 4/5, 267-284.

Lee, K. E. 1985. Earthworms: their ecology and relationships with soils and land use. London: Academic Press.

Meek, B., Rechel, E., Carter, L. and Detar, W., 1989. Changes in Infiltration Under Alfalfa as Influenced by Time and Wheel Traffic. Soil Science Society of America Journal, 53(1), $238-241$.

Nilson B., Sidle R.C., Klint K.E.S., Bøggild C.E., and Broholm K., 2001. Mass Transport and Scale-dependent Hydraulic Tests in a Heterogeneous Glacial Till - Sand Lens Unconfined Sandy Aquifer System. Journal of Hydrology, 243, 162-179.

Roldin, M., Mark, O., Kuczera, G., Mikkelsen, P. S. and Binning, P. J., 2012. Representing soakaways in a physically distributed urban drainage model - Upscaling individual allotments to an aggregated scale. Journal of Hydrology, 414-415, 530-538.

Roldin, M., Locatelli L., Mark O., Mikkelsen P. S. and Binning P. J., 2013. A Simplified Model of Soakaway Infiltration Interaction with a Shallow Groundwater Table. Journal of Hydrology, 497 (0), 165-75. 
Rosenbom, A. E., Therrien, R., Refsgaard, J. C., Jensen, K. H., Ernstsen, V. and Klint, K.E.S., 2009. Numerical analysis of water and solute transport in variably-saturated fractured clayey till. Journal of Contaminant Hydrology, 104 (1-4), 137-152.

Sidle R.C., Nilsson B., Hansen M., Fredericia J. (1998). Spatially varying hydraulic and solute transport characteristics of a fracture till determined by field tracer test, Funen, Denmark.Water Resour Res 34(10), 2515-2527.

Smetak, K.M., Johnson-Maynard,, J.L.,Lloyd, J.E. (2011). Earthworm population density and diversity in different aged urban systems. Applied Soil Ecology, 37, 161-168.

Samardzioska T. and Popov V. 2005. Numerical comparison of the equivalent continuum, nonhomogeneous and dual porosity models for flow and transport in fractured porous media. Advances in Water Resources 28, (3), 235-255.

Therrien R., McLaren R.G., Sudicky E.A. and Panday S.M, (2009). HydroGeoSphere: A Threedimensional Numerical Model Describing Fully-integrated Subsurface and Surface Flow and Solute Transport. Code documentation and user's guide. Groundwater Simulations Group.

Tsakiroglou C.D., Klint K.E.S., Nilsson B, Theodoropoulou M.A. and Aggelopolous C.A., 2012. From aperture characterization to hydraulic properties of fractures. Geoderma, 181-182, 65-77.

Virahsawmy, H. K., Stewardson, M. J., Vietz, G. and Fletcher, T. D., 2014. Factors that affect the hydraulic performance of raingardens: implications for design and maintenance. Water Science and Technology: A Journal of the International Association on Water Pollution Research, 69 (5), 982-988.

Wang, J. S. Y. and Narasimhan, T. N, 1985. Hydrologic Mechanisms Governing Fluid Flow in a Partially Saturated, Fractured, Porous Medium. Water Resources Research, 21 (12), 1861-1874.

Witherspoon, P. A., Wang, J. S. Y., Iwai, K. and Gale, J. E., 1980. Validity of Cubic Law for fluid flow in a deformable rock fracture. Water Resources Research, 16 (6), 1016-1024.

Woods-Ballard, B., Kellagher, R., Martin, P., Jefferies, C., Bray, R. and Shaffer, P., 2007. The SUDS manual (C697). CIRIA. Available from: https://repository.abertay.ac.uk/jspui/handle/10373/994. 
